\title{
Peran Sikap Keuangan dalam Mengintervensi Pengaruh Literasi Keuangan Terhadap Perilaku Manajemen Keuangan Pekerja di Cikarang.
}

\author{
Wisnu Setyawan ${ }^{1)}$; Siska Wulandari ${ }^{2}$ \\ ${ }^{1,2)}$ Fakultas Ekonomi Dan Bisnis, Universitas Pelita Bangsa, Bekasi, \\ email : wisnu.setyawan@pelitabangsa.ac.id
}

\section{ARTICLES INFORMATION}

ABSTRACT

\section{JURNAL SEKURITAS \\ (Saham, Ekonomi, Keuangan dan Investasi ) \\ Vol.4, No.1, September 2020 Halaman : 15-23 \\ (c) LPPM \& Prodi Manajemen UNVERSITAS PAMULANG}

\section{ISSN (online) : 2581-2777 ISSN (print) : : 2581-2696}

\section{Keyword :}

Sikap keuangan; perilaku keuangan pekerja; literasi keuangan; perilaku manajemen keuangan

JEL. classification : C33, G21, G24, N15, N25

\section{Contact Author : \\ PRODI MANAJEMEN UNPAM \\ JL.Surya Kencana No.1 \\ Pamulang Tangerang Selatan - Banten \\ Telp. (021) 7412566, Fax (021) 7412491 Email : sekuritas@unpam.ac.id}

Perilaku manajemen keuangan dipengaruhi oleh beberapa faktor diantaranya literasi dan sikap keuangan, sementara literasi keuangan sendiri menjadi faktor penentu sikap keuangan seseorang. Pekerja di Cikarang sebagian besar merupakan pekerja muda berpenghasilan cukup. Penelitian ini mengambil sampel atas 126 tanggapan responden yang terdiri dari 32 pria dan 94 wanita pekerja di Cikarang. Data diolah dengan uji statistik regresi jalur menggunakan SPSS dengan add on Process v3.4 dari Andrew F. Hayes.

Hasil penelitian menunjukan bahwa sikap keuangan tidak hanya berpengaruh langsung terhadap perilaku manajemen keuangan pekerja, namun juga memiliki peran dalam memediasi pengaruh literasi keuangan terhadap perilaku manajemen keuangan pekerja di Cikarang.

Financial management behavior is influenced by several factors including literacy and financial attitudes, while financial literacy itself is a determining factor in one's financial attitude. Workers in Cikarang are mostly young workers who earn enough. This study sampled 126 respondents' responses consisting of 32 male and 94 female workers in Cikarang. Data were processed by path regression statistical tests using SPSS with add on Process v3.4 from Andrew F. Hayes.

The results show that financial attitudes not only directly influence the behavior of workers 'financial management, but also have a role in mediating the effect of financial literacy on the behavior of workers' financial management in Cikarang. . 


\section{A. PENDAHULUAN}

Sejak ditetapkannya pemindahan kawasan industri dari Jakarta ke kota-kota satelit seperti kabupaten Bekasi, khususnya daerah Cikarang dan sekitarnya menjadi salah satu tempat pengembangan kawasan industri. Kawasan ini terus berkembang, bahkan menjadi kawasan industri terbesar di Asia Tenggara. Dalam advertorial (Advertorial - detikFinance, 2017) disebutkan bahwa Cikarang mampu menyumbang sebesar $34,46 \%$ Penanaman Modal Asing nasional, serta $22-45 \%$ volume ekspor nasional.

Kota Cikarang adalah bagian dari kabupaten Bekasi yang merupakan kabupaten dengan Upah Minimun Kota (UMK) kedua tertinggi setelah kabupaten Karawang, padahal Jawa Barat yang merupakan provinsi dari kedua kota ini termasuk dalam tiga provinsi dengan Upah Minimum Provininsi (UMP) terendah di Indonesia (Debora, 2018).

Ditetapkannya UU No. 13 Tahun 2003 tentang Ketenagakerjaan berimbas pada banyaknya perusahaan yang lebih memilih kebijakan untuk membayar upah overtime daripada harus menambah jumlah karyawan, sehingga pada kenyataannya pendapatan yang diterima rata-rata pekerja di Cikarang pada umumnya diatas UMK.

Dengan pendapatan perkapita diatas rata-rata tidak serta-merta menjadikan para pekerja di Cikarang hidup layak. Hal ini dikarenakan tingkat kebutuhan dan biaya hidup di kota indusitri jauh lebih tinggi dibandingkan di daerah lain. Oleh karena itu pekerja dituntut lebih bijak dalam perilaku pengelolaan sumberdaya keuangannya.

Perilaku manajemen keuangan pada pekerja dipengaruhi oleh tingkat literasi seseorang, sebagaimana ditunjukan dari hasil penelitian pada pekerja di surabaya (Bella Francisca Himalaya Putri, 2018), yang dipertegas oleh beberapa penelitian selanjutnya tentang perilaku manajemen keuangan pekerja di beberapa kota indutri lainnya seperti jakarta (Putri \& Lestari, 2019).

Berdasarkan sumber dari hasil penelitian lainnya, bahwa perilaku manajemen keuangan juga dipengaruhi oleh faktor-faktor lain, diantaranya sikap keuangan (Humaira \& Sagoro, 2018). Penelitian lain yang menunjukan bahwa perilaku manajemen keuangan dipengaruhi oleh sikap keuangan adalah penelitian yang dilakukan pada mahasiswa ekonomi STIE Bank BPD Jateng di Semarang (Pradiningtyas \& Lukiastuti, 2019).

\section{B. KAJIAN LITERATUR}

Manajemen adalah tata kelola organisasi yang meliputi pokok kegiatan perencanaan, pendelegasian wewenang dan tanggungjawab, pengambilan keputusan, dan pengendalian. Manajemen Keuangan (Van Horne \& Wachowicz , 2005) adalah segala aktivitas yang berhubungan dengan perolehan, pendanaan, dan pengelolaan aktiva dengan beberapa tujuan menyeluruh.

Teori Perilaku Terencana (Theory of Planned Behavior) merupakan pengembangan lebih lanjut dari Teori Perilaku Beralasan (Theory of Reasoned Action). Teori Perilaku Terencana merupakan kerangka berpikir konseptual yang bertujuan untuk menjelaskan faktor-faktor yang berkontribusi terhadap perilaku tertentu (Ajzen, 1991). Secara umum, teori tersebut menjelaskan alasan seseorang dalam bertindak.

Teori ini terdiri dari 3 konsep, diantaranya : attitude towards the behavior (sikap terhadap perilaku), subjective norm (norma subjektif) dan perceived behavioural control (kontrol perilaku yang dirasakan). Sikap terhadap perilaku mengacu pada tingkat di mana seseorang membentuk evaluasi positif atau negatif terhadap perilaku. Norma subjektif mengacu pada tekanan sosial yang dirasakan untuk melakukan atau tidak melakukan perilaku tersebut. Tekanan sosial berasal dari referensi yang menonjol seperti orangtua, teman, aktifitas, minat, dan opini. Kontrol perilaku yang dirasakan mengacu pada persepsi orang tentang kemampuan mereka dalam melakukan perilaku tertentu. 
Dalam sebuah publikasi ilmah yang berjudul "What is Behavioral Finance?" menjelaskan bahwa perilaku manajemen keuangan adalah upaya pola penalaran investor, termasuk proses emosional yang terlibat dan sejauh mana mereka mempengaruhi proses pengambilan keputusan (Statman, 2008).

Sebuah artikel yang berjudul "An Empirical Analysis Of Inter Linkages Between Financial Attitudes, Financial Behaviour And Financial Knowledge Of Salaried Individuals" menjelaskan bahwa literasi keuangan adalah kemampuan untuk membuat penilaian berdasarkan informasi dan kemampuan untuk mengambil keputusan yang efektif dalam penggunaan dan pengelolaan keuangan (Bhushan, Puneet Yajulu, 2014).

Literasi keuangan adalah aktifitas seseorang dalam meningkatkan pengetahuan maupun keterampilannya dalam bidang keuangan yang meliputi pengetahuan umum keuangan, pengetahuan manajemen keuangan, pengetahuan mengenai tabungan dan investasi, dan pengetahuan mengenai manfaat dan resiko produk-produk keuangan.

Pengaruh literasi keuangan terhadap perilaku manajemen keuangan dibuktikan dari hasil penelitian pada 75 mahasiswa di Sumatera (Laily, 2016). Penelitian ini membuktikan bahwa literasi keuangan berpengaruh positif terhadap perilaku manajemen keuangan mahasiswa di Sumatera. Hal serupa ditegaskan oleh hasil penelitian pada 113 mahasiswa fakultas ekonomi Universitas Muhammadiyah Gresik (Fatimah \& Susanti, 2018). Hasil dari penelitian ini menunjukan bahwa literasi keuangan berpengaruh positif terhadap perilaku manajemen keuangan mahasiswa di Universitas Muhammadiyah Gresik.

Penelitian serupa yang mempertegas pengaruh literasi keuangan terhadap perilaku manajemen keuangan antara lain hasil penelitian dilakukan pada mahasiswa program studi manajemen Universitas Terbuka yang menunjukan adanya pengaruh positif literasi keuangan terhadap perilaku manajemen keuangan mahasiswa di Universitas Terbuka (Hamdani, 2018). Adapun penaruh literasi keuangan terhadap perilaku manajemen keuangan pekerja ditunjukan dari hasil penelitian yang dilakukan pada pekerja di Jakarta (Putri \& Lestari, 2019).

Namun berbeda dari hasil keempat penelitan diatas, penelitian pada masyarakat di surabaya menunjukan bahwa literasi keuangan tidak berpengaruh terhadap perilaku manajemen keuangan masyarakat di surabaya (Bella Francisca Himalaya Putri, 2018). Terlebih lagi hasil penelitian yang dilakukan pada pelaku UMKM di Kecamatan Mojolaban Kabupaten Sukoharjo menunjukan bahwa literasi keuangan berpengaruh negatif terhadap perilaku manajemen keuangan pelaku UMKM (Saputri, 2019).

Sikap adalah keadaan mental dan taraf dari kesiapan, yang diatur melalui pengalaman yang memberikan pengaruh dinamik atau terarah terhadap respons individu pada semua objek dan situasi yang berkaitan dengannya (Allport, 1935) dalam (Farr, 1994). Sikap keuangan adalah intepretasi daripada pola berfikir, pendapat serta penilaian tentang keuangan yang meliputi orientasi terhadap keuangan pribadi, filosofi uang, keamanan uang, dan penilaian uang pribadi.

Pengaruh sikap keuangan terhadap perilaku manajemen keuangan dibuktikan oleh hasil penelitian pada pelaku UMKM Sentra Kerajinan Batik di Bantul (Humaira, 2017). Hasil penelitian ini juga membuktikan bahwa perilaku manajemen keuangan juga dipengaruhi oleh sikap keuangan. Hasil serupa ditunjukan pada penelitian yang dilakukan pada sejumlah keluarga di Sidoarjo (Widyaningrum \& Kurniawati, 2018).

Literasi keuangan yang terkait dengan pengetahuan umum keuangan, pengetahuan manajemen keuangan, pengetahuan mengenai tabungan dan investasi, dan pengetahuan mengenai resiko memiliki peran dalam mempengaruhi sikap keuangan maupun perilaku manajemen keuangan seseorang.

Berpedoman kepada temuan penelitian terdahulu, dapat dikembangkan hipotesis pertama $(\mathrm{H} 1)$ literasi keuangan berpengaruh terhadap sikap keuangan pekerja di Cikarang, lalu hipotesis kedua(H2) literasi keuangan berpengaruh terhadap perilaku manajemen keuangan pekerja di Cikarang.

Sikap keuangan yang merupakan intepretasi daripada pola berfikir, pendapat serta penilaian tentang keuangan yang meliputi orientasi terhadap keuangan pribadi, filosofi uang, 
keamanan uang, dan penilaian uang pribadi memiliki peran dalam mempengaruhi perilaku manajemen keuangan seseorang. Atas dasar tersebut ditetapkan hipotesis ketiga(H3) yaitu sikap keuangan berpengaruh terhadap perilaku manajemen keuangan pekerja di Cikarang, lalu hipotesis keempat(H4) literasi keuangan berpengaruh secara tidak langsung terhadap perilaku manajemen keuangan melalui intervensi sikap keuangan pekerja di Cikarang, dan hipotesis kelima(H5) yakni sikap keuangan mengintervensi pengaruh literasi keuangan terhadap perilaku manajemen keuangan pekerja di Cikarang.

\section{METODOLOGI PENELITIAN}

Penelitian ini menggunakan data hasil tanggapan responden atas pernyataan kualitatif yang diskalakan menggunakan skala likert untuk menghasilkan data kuantitatif. Guna menjawab hipotesis penelitian, data diolah melalui metode pengujian statistik.

Penelitian dilakukan pada bulan Juli sampai dengan oktober 2019. Lokasi penelitian dilakukan wilayah kawasan industri di Cikarang dan sekitarnya.

Populasi adalah wilayah generalisasi terdiri atas objek/subjek yang mempunyai kualitas dan karakteristik tertentu, ditetapkan oleh peneliti untuk dipelajari dan kemudian ditarik kesimpulan (Sugiyono, 2016).

Berdasarkan hasil perhitungan dengan rumus Slovin, jumlah sampel minimum yang diharuskan pada penelitian ini sebanyak 100 pekerja di Cikarang. Data diperoleh dari hasil tanggapan 126 responden melalui angket yang didistribusikan secara acak menggunakan aplikasi google form. Responden dalam penelitian ini adalah pekerja berstatus karyawan aktif pada perusahaan yang terdapat di Cikarang dan sekitarnya.

Selanjutnya hasil dari jawaban responden diukur menggunakan skala interval Likert. Skala likert adalah skala yang menggunakan beberapa butir pertanyaan untuk mengukur perilaku individu dengan merespon 5 titik pilihan pada setiap butir pertanyaan, sangat setuju, setuju, tidak memutuskan, tidak setuju, dan sangat tidak setuju (Budiaji, 2013).

Setiap butir yang mewakili indikator, dan setiap indikator yang mewakili masing-masing variabelnya dalam penelitian ini dapat dilihat berdasarkan definisi operasional variabelvariabel berikut :

Tabel 1. Definisi Operasional Variabel

\begin{tabular}{lll}
\hline \multicolumn{1}{c}{ Variabel } & \multicolumn{1}{c}{ Indikator } & \multicolumn{1}{c}{ Butir Pernyataan } \\
\hline Perilaku & 1. Jenis-jenis perencanaan dan anggaran keuangan & PMK1, PMK2, PMK3 \\
Manajemen & yang dimiliki & \\
Keuangan & 2. Teknik dalam menyusun perencanaan keuangan & PMK4, PMK5, PMK6 \\
& 3. Kegiatan menabung & PMK7, PMK8 \\
& 4. Kegiatan asuransi, pensiun, dan pengeluaran tidak & PMK9, PMK10, PMK11 \\
& terduga & \\
& 5. Kegiatan investasi, kredit/hutang, dan tagihan & PMK12, PMK13, PMK14 \\
& 6. Monitoring pengelolaan keuangan & PMK15, PMK16, PMK17 \\
& 7. Evaluasi pengelolaan keuangan & PKM18, PMK19, PK20 \\
\hline Literasi & 1. Pengetahuan umum keuangan & LK1, LK2 \\
Keuangan & 2. Pengetahuan manajemen uang & LK3 \\
& 3. Pengetahuan tentang tabungan dan investasi & LK4, LK5 \\
& 4. Pengetahuan mengenai risiko & LK6, LK7 \\
\hline Sikap & 1. Orientasi Terhadap keuangan pribadi & SK1, SK2, SK3 \\
Keuangan & 2. Filsafat Utang & SK4 \\
& 3. Keamanan Uang & SK5, SK6 \\
& 4. Menilai Keuangan Pribadi & SK7, SK8 \\
\hline
\end{tabular}

Sumber : Humaira, 2017

Uji validitas digunakan untuk menguji seberapa baik tingkat kecermatan instrumen penelitian sebagai alat ukur yang mewakili masing-masing variabel. Pengujian dilakukan

Jurnal SEKURITAS (Saham, Ekonomi, Keuangan dan Investasi ), Vol.4, No.1, September 2020.....18 
dengan cara mengkorelasikan antara skor tiap butir pernyataan dengan menggunakan rumus korelasi product moment. Instrumen penelitian dinyatakan valid apabila masingmasing butir pernyataan memiliki nilai rhitung > dari rtabel.

Uji reliabilitas dilakukan guna mengukur konsistensi instrumen sebagai alat ukur variabel. Intrumen yang reliabel artinya instrument yang bila digunakan beberapa kali untuk mengukur obyek yang sama akan menghasilkan data yang sama, sedang hasil penelitian yang reliable bila terdapat kesamaan data dalam waktu yang berbeda (Ghozali \& Ratmono, 2017).

Suatu konstruk atau variabel dikatakan reliabel jika memberikan nilai cronbach alpha > 0,60. Menurut Sekaran (2000) dalam (Saputri, 2019), bila nilai alpha antara 0,8-1,0 dikategorikan reliabilitas baik, bila nilai alphanya 0,6-0,79 dikategorikan reliabilitas dapat diterima, dan bila nilai alphanya kurang dari 0,6 dikategorikan reliabilitasnya kurang baik.

Dari hasil uji validitas seluruh variabel nilai $r$-hitung $>$ dari $r$-tabel $(N-126=124, \alpha=0,05)$, dimana r-tabel adalah 0,1472, berarti seluruh butir pernyataan adalah Valid.

Nilai cronbach alpha baik variabel literasi keuangan $(0,777)$, sikap keuangan $(0,704)$ dan perilaku manajemen keuangan $(0,864)$ lebih besar dari batas kritis $(0,6)$, sehingga dapat dikategorikan instumen penelitian memiliki reliabilitas yang baik.

\section{HASIL DAN PEMBAHASAN}

Karakteristik responden yang dipilih secara acak dideskripsikan berdasarkan jenis kelaminnya dapat dilihat pada tabel 5 . Instrumen yang digunakan untuk penelitian ini adalah kuesioner yang dibagikan kepada 126 responden, yakni pekerja di Cikarang yang tercatat sebagai karyawan aktif di perusahaan tempat mereka bekerja. 126 responden tersebut terdiri dari 32 (25\%) pekerja berjenis kelamin Laki-laki dan 94 (75\%) pekerja berjenis kelamin perempuan.

Tabel 2. Karakteristik Responden Berdasarkan Jenis Kelamin

\begin{tabular}{ccc}
\hline Jenis Kelamin & Jumlah Responden & Presentase \\
\hline Laki-laki & 32 & $25 \%$ \\
\hline Perempuan & 94 & $75 \%$ \\
\hline Total & 126 & $100 \%$ \\
\hline
\end{tabular}

Sumber : Data Penelitian, 2019

Hasil uji normalitas distribusi dapat dilihat dari bentuk diagram yang membentuk lonceng, yang artinya residual data terdistribusi normal, dimana nilai mean, modus, dan median residual terdistribusi sejajar.

Uji multikolinearitas bertujuan untuk menguji apakah model regresi ditemukan adanya kolerasi antara variabel literasi keuangan (LK_X1) dengan variabel sikap keuangan (SK_X2). Multikolinearitas dapat dilihat pada tabel 6, dari nilai Tolerance dan nilai lawannya yaitu Variance Inflation Factor (VIF). Nilai cutoff yang umum dipakai untuk menunjukkan adanya nilai multikolinearitas adalah nilai tolerance $\geq 0,10$ dan dengan nilai VIF $\leq 10$ (Ghozali \& Ratmono, 2017).

Tabel 3. Hasil Uji Multikolinieritas

\begin{tabular}{llrrr}
\hline & & \multicolumn{3}{c}{ Collinearity Statistics } \\
\cline { 2 - 5 } Model & Tolerance & VIF \\
\hline 1 & SK & &, 847 & 1,180 \\
\cline { 2 - 5 } & LK &, 847 & 1,180 \\
\hline
\end{tabular}

a. Dependent Variable: PMK

Sumber : Data Penelitian, 2019

Dari hasil dW diketahui nilai dW-tabel untuk 2 variabel penjelas $(\mathrm{K})$ dengan jumlah observasi $(\mathrm{N})=126$ adalah $\mathrm{dL}=1,6771$ dan $\mathrm{dU}=1,7415$ (untuk mempermudah lihat dilampiran tabel $\mathrm{dW}$ ), sedangkan jika kita lihat nilai dW-hitung dari tabel 4.7 adalah 2,039, Jurnal SEKURITAS (Saham, Ekonomi, Keuangan dan Investasi), Vol.4, No.1, September 2020.....19 
maka dapat disimpulkan tidak terdapat autokorelasi pada masing-masing variabel penjelas karena dU lebih kecil dari dW-hitung, dan nilai dW-hitung dibawah 4 dikurangi $\mathrm{dU}$ (dU $<\mathrm{dW}$ $<4$-dU) atau 1,7415 <2,153<2,2585 (4 - 1,7152).

Hasil uji heteroskedastisitas dapat dilihat pada sebaran titik dalam diagram yang tidak membentuk pola simetris, yang artinya data bebas dari sifat heteroskedastisitas.

Pada hasil kalkulasi SPSS dengan add on PROCESS v3.0 for SPSS dari Andrew Hayes, dapat dilihat nilai koefisien variabel prediktor terhadap variabel terikatnya, dimana :

SK $=18,1638+0,3917($ LK $)+e$, artinya jika Literasi Keuangan dianggap konstan maka tingkat nilai Sikap Keuangan sebesar 18,1638, atau jika diasumsikan nilai konstanta $=0$, maka setiap kenaikan 1 Literasi Keuangan akan mempengaruhi Sikap Keuangan sebesar 0,3917. PMK $=18,3005+1,2492($ LK $)+0,9961($ SK $)+e$, artinya jika Literasi Keuangan dan Sikap Keuangan dianggap konstan maka tingkat Perilaku Manajemen Keuangan sebesar 18,3005, atau jika diasumsikan nilai konstanta $=0$, maka kenaikan 1 Literasi Keuangan akan mempengaruhi Perilaku Manajemen Keuangan sebesar 1,2492, dan kenaikan 1 Sikap Keuangan akan mempengaruhi Perilaku Manajemen Keuangan sebesar 0,9961.

Koefisien Determinasi ( $(2)$ digunakan untuk mengukur seberapa jauh kemampuan model dalam menerangkan variansi variabel terikat. Nilai koefisien determinasi (r2) adalah koefisien yang menjelaskan seberapa besar proporsi variansi dalam variabel terikat yang dapat dijelaskan oleh variabel-variabel bebas secara bersama-sama. Nilai r2 koefisien determinasi berkisar antara $0-1$, nilai $r 2$ sama dengan nol $(r 2=0)$ menunjukkan bahwa tidak ada pengaruh antara variabel bebas terhadap variabel terikat. Bila r2 semakin besar mendekati 1 menunjukkan semakin kuat pengaruh variabel bebas tehadap variabel terikat, dan bila r2 semakin kecil mendekati 0 menunjukkan semakin kecil pengaruh variabel bebas terhadap variabel terikat(Ghozali \& Ratmono, 2017).

Tabel 4. Uji Koefisien Determinasi

\begin{tabular}{ccccc}
\hline \multicolumn{5}{c}{ Model 1 } \\
\hline $\mathbf{R}$ & R-Square & MSE & F & p \\
\hline 0,3908 & 0,1527 & 12,1587 & 22,3552 & 0,0000 \\
\hline 0,7551 & 0,5702 & Model 2 & \\
\hline
\end{tabular}

Sumber : Data Penelitian, 2019

Pada model pertama dimana hubungan literasi keuangan dalam mempengaruhi sikap keuangan berkontribusi sebesar $15,27 \%$. Sementara pada model kedua dimana kontribusi literasi keuangan dan sikap keuangan dalam mempengaruhi perilaku manajemen keuangan sebesar 57,02\%. Pengujian hipotesis dalam penelitian kali ini menggunakan 2 model pengujian, yaitu uji pengaruh langsung masing-masing variabel penjelas terhadap variabel terikat dan uji pengauh tidak langsung variabel penjelas melaui variabel intervening terhadap variabel terikat.

Pengujian pengaruh variabel bebas terhadap variabel terikat secara parsial dengan membandingkan nilai t-hitung terhadap nilai t-tabel masing-masing variabel pada hasil uji t. Adapun dalam pegujian parsial penting untuk melihat nilai signifikansinya dimana nilai $\alpha<$ 0,05 , karena akan mengisyaratkan bahwa hasil pengujian sampel dapat mewakili atau digeneralisasikan terhadap populasinya.

Tabel 5. Hasil Uji Parsial Pengaruh Literasi Keuangan Terhadap Sikap Keuangan

\begin{tabular}{lcccc}
\hline \multicolumn{5}{c}{ Kriterium : Sikap Keuangan } \\
\hline & Koefisien & S.E & $\mathbf{T}$ & $\mathbf{P}$ \\
\hline Konstanta & 18,1638 & 2,5359 & 7,1627 & 0,0000 \\
\hline Lit. Keu. & 0,3917 & 0,0828 & 4,7281 & 0,0000 \\
\hline
\end{tabular}

Sumber : Data Penelitian, 2019 
Dari tabel diatas dapat dilihat signifikansi $(p)$ variabel literasi keuangan adalah $0,00 \leq 0,05$ dengan nilai t-hitung 4,7281 lebih besar dari nilai t-tabel yaitu 1,6573, maka kesimpulannya adalah $\mathbf{H}_{1}$ diterima, Literasi keuangan berpengaruh positif terhadap Sikap keuangan pekerja di Cikarang.

Tabel 6. Hasil Uji Parsial Pengaruh Literasi Keuangan Dan Sikap Keuangan Terhadap Perilaku

\begin{tabular}{lcccc}
\hline \multicolumn{5}{c}{ Kriterium : Perilaku Manajemen Keuangan } \\
\hline & Koefisien & S.E & T & p \\
\hline Konstanta & 18,3005 & 5,3547 & 3,4176 & 0,0009 \\
\hline Literasi Keu. & 1,2492 & 0,1598 & 7,8158 & 0,0000 \\
\hline Sikap Keu. & 0,9961 & 0,1595 & 6,2458 & 0,0000 \\
\hline Sun
\end{tabular}

Sumber : Data Penelitian, 2019

Dari tabel diatas dapat dilihat signifikansi variabel Literasi keuangan $0,000 \leq 0,05$ dengan nilai t-hitung 7,8158 adalah lebih besar dari nilai t-tabel yaitu 1,6573, maka kesimpulannya adalah $\mathbf{H}_{2}$ diterima, Literasi keuangan berpengaruh positif terhadap perilaku manajemen keuangan pekerja di Cikarang.

Signifikansi variabel Sikap keuangan $0,000 \leq 0,05$ dengan nilai t-hitung 6,2458 adalah lebih besar dari nilai t-tabel yaitu 1,6573, maka kesimpulannya adalah $\mathbf{H}_{3}$ diterima, Sikap keuangan berpengaruh positif terhadap perilaku manajemen keuangan pekerja di Cikarang.

Tabel 7. Hasil Uji Pengaruh Literasi Keuangan Terhadap Terhadap Perilaku Manajemen Keuangan Melalui Mediasi Sikap Keuangan Indirect effect of $\mathrm{X}$ on $\mathrm{Y}$

\begin{tabular}{lccc}
\hline & Effect & BootLLCl & BootULCl \\
\hline Sikap Keu. & 0,3901 & 0,1952 & 0,5758 \\
\hline Sikap Keu. & Completely standardized inderect effect X on Y \\
\hline
\end{tabular}

Sumber : Data Penelitian, 2019

Besarnya pengaruh tidak langsung dapat dilihat dari koefisien terstandar efek tidak langsung $X$ ke $Y$ yakni sebesar 0,1568 . Jadi dapat disimpulkan bahwa $\mathbf{H}_{4}$ diterima, Literasi keuangan berpengaruh secara tidak langsung terhadap perilaku manajemen keuangan melalui intervensi sikap keuangan pekerja di Cikarang.

Untuk melihat ada tidaknya peran mediasi varibel sikap keuangan, kita bisa melihat pada output di bagian indirect effect of $X$ on $Y$. Dimana hasilnya menunjukan nilai koefisien tidak langsung sebesar 0,3901 dengan interval kepercayaan dari hasil bootstrap terendah yakni 0,1952 (BootLLCI) dan nilai interval tertinggi adalah 0,5758 (BootULCl). Jika rentang nilai antara BootLLCl dan BootULCl itu tidak mencakup nilai nol (0), maka dapat disimpulkan estimasi signifikan dan terjadi efek mediasi. Jadi dapat disimpulkan bahwa $\mathbf{H}_{5}$ diterima, Sikap keuangan mengintervensi pengaruh literasi keuangan terhadap perilaku manajemen keuangan pekerja di Cikarang. 


\section{E. KESIMPULAN}

Sikap keuangan tidak hanya berpengaruh langsung terhadap perilaku manajemen keuangan pekerja, namun juga berperan dalam memediasi pengaruh literasi keuangan terhadap perilaku manajemen keuangan pekerja di Cikarang.

Hasil penelitian ini menunjukan bahwa literasi keuangan menjelaskan dengan baik pengaruhnya terhadap perilaku manajemen keuangan pekerja di Cikarang, baik langsung maupun tidak langsung, dan literasi keuangan juga secara langsung mempengaruhi sikap keuangan pekerja di Cikarang.

Hasil dari penelitian ini juga menunjukan bahwa literasi keuangan dan sikap keuangan pekerja memberikan kontribusi determinasi dalam menjelaskan perilaku manajemen keuangan pekerja di Cikarang sebesar 57,02\%.

Terdapat kontribusi yang cukup besar dari faktor-faktor lain diluar model, yakni sebesar $42,98 \%$, untuk itu disarankan untuk penelitian selanjutnya menambahkan variabel lain sebagai variabel eksogen maupun variabel intervening dalam menjelaskan perilaku manajemen keuangan

\section{DAFTAR PUSTAKA}

Advertorial - detikFinance. (2017). Kawasan Industri Cikarang Terbesar di Asia Tenggara. Finance.Detik.Com. https://finance.detik.com/advertorial-news-block/d3619600/kawasan-industri-cikarang-terbesar-di-asia-tenggara

Ajzen, I. (1991). The theory of planned behavior. Organizational Behavior and Human Decision Processes. https://doi.org/10.1016/0749-5978(91)90020-T

Alfiah, S., Andriani, J., Lesmana, R., Sunardi, N., \& Furyanah, A. (2019). Manajemen Pengelolaan Desa Wisata Pada Desa Cimanggu, Kecamatan Cisalak, Kabupaten Subang, Privinsi Jawa Barat (Studi Kasus pada Curug Paok dan Bukit Pasir Jaka). Jurnal Abdi Masyarakat Humanis, 1(1).

Bella Francisca Himalaya Putri. (2018). Pengaruh Literasi Keuangan, Gaya Hidup, Dan Kontrol Diri Terhadap Perilaku Pengelolaan Keuangan Pekerja Di Surabaya. STIE Perbanas Surabaya.

Bhushan, Puneet Yajulu, M. (2014). an Empirical Analysis of Inter Linkages Between Financial Attitudes, Financial Behaviour and Financial Knowledge of Salaried Individuals. Indian Journal of Commerce \& Management Studies, V(3), 58-64.

Budiaji, W. (2013). Skala Pengukuran dan Jumlah Respon Skala Likert. Jurnal IImu Pertanian Dan Perikanan.

Debora, Y. (2018). Daftar UMP 2019: Jakarta Tertinggi, Yogyakarta Terendah. https://tirto.id/daftar-ump-2019-jakarta-tertinggi-yogyakarta-terendah-c88h

Editorial - Wartakota. (2019). Bupati Bekasi Minta Perusahaan di Kawasan Industri Serap Tenaga Kerja Lokal. Wartakotalive.Com. https://wartakota.tribunnews.com/2019/06/26/bupati-bekasi-minta-perusahaan-dikawasan-industri-serap-tenaga-kerja-lokal

Farr, R. (1994). Attitudes, social representations and social attitudes. Papers on Social Representations. 
Fatimah, N., \& Susanti. (2018). Pengaruh Pembelajaran Akuntansi Keuangan, Literasi Keuangan, dan Pendapatan Terhadap Perilaku Keuangan Mahasiswa Fakultas Ekonomi Universitas Muhammadiyah Gresik. Jurnal Pendidikan Akuntansi (JPAK), 6(1).

Ghozali, I., \& Ratmono, D. (2017). Analisis Multivariat dan Ekonometrika. In Universitas Diponegoro.

Hakim, L., Sunardi, N. (2017). Determinant of leverage and it's implication on company value of real estate and property sector listing in IDX period of 2011-2015. Man in India, 97(24), pp. 131-148

Hamdani, M. (2018). Analisis Tingkat Literasi Keuangan dan Pengaruhnya terhadap Perilaku Keuangan pada Mahasiswa Prodi Manajemen Universitas Terbuka. Jurnal Bakti Masyarakat Indonesia, 1(1), 139-145.

Humaira, I. (2017). Pengaruh Pengetahuan Keuangan, Sikap Keuangan Dan Kepribadian Terhadap Perilaku Manajemen Keuangan Pada Pelaku Umkm Sentra Kerajinan Batik. Skripsi Universitas Negeri Yogyakarta, 194.

Kadim, A., Sunardi, N., \& Husain, T. (2020). The modeling firm's value based on financial ratios, intellectual capital and dividend policy. Accounting, 6(5), 859-870.

Laily, N. (2016). Pengaruh Literasi Keuangan Terhadap Perilaku Mahasiswa Dalam Mengelola Keuangan. Journal of Accounting and Business Education, 1(4). https://doi.org/10.26675/jabe.v1i4.6042

Putri, N. A., \& Lestari, D. (2019). Pengaruh Gaya Hidup dan Literasi Keuangan Terhadap Pengelolaan Keuangan Tenaga Kerja Muda di Jakarta. AKURASI: Jurnal Riset Akuntansi Dan Keuangan, 1(1), 31-42. https://doi.org/10.36407/akurasi.v1i1.61

Saputri, M. A. (2019). Pengaruh Tingkat Literasi Keuangan Terhadap Pengelolaan Keuangan Pada Pelaku Umkm Kecamatan Mojolaban Kabupaten Sukoharjo. Institut Agama Islam Negeri Surakarta.

Statman, M. (2008). What Is Behavioral Finance? In Handbook of Finance. https://doi.org/10.1002/9780470404324.hof002009

Sugiyono, P. D. (2016). metode penelitian kuantitatif, kualitatif,dan R\&D. CV. Alfabeta.

Sunardi, N. (2015). Pengaruh Profitabilitas, Firm Size, Risiko Bisnis, Asset Growth, Leverage, Kebijakan Dividen Terhadap Institutional Ownership (Perusahaan Property \& Real Estate yang terdaftar di Bursa Efek Indonesia Tahun 2011-2014). INOVASI Jurnal IImiah IImu Manajemen, 2(2), 62-81.

Sunardi, N. (2020). Penilaian Kinerja Keuangan menggunakan Economic Value Added (EVA) dan Market Value Added (MVA) dengan Time Series Approach pada Industri Semen di Indonesia. JIMF (Jurnal IImiah Manajemen Forkamma), 3(2).

Widyaningrum, S., \& Kurniawati, S. L. (2018). Pengaruh Sikap Keuangan, Pengetahuan Keuangan Dan Pengalaman Keuangan Terhadap Perilaku Pengelolaan Keuangan Keluarga Di Sidoarjo. STIE Perbanas, 45, 39.

Wulandari, A., \& Mulyanto, H. (2010). (2010). Penelitian Metode dan Analisis. CV. Agung. 